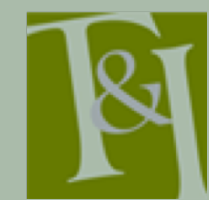

The International Journal for Translation \& Interpreting Research trans-int.org

\section{Translating the poetics/politics of silence: The case of Catalan and Spanish translations of Vercors' Le silence de la mer (1942)}

\author{
Maria Dasca \\ Harvard University/Universitat Pompeu Fabra, Spain \\ maria.dasca@upf.edu
}

DOI: 10.12807/ti.11222.2020.a03

\begin{abstract}
The aim of this article is to analyze the Catalan and Spanish translations of Vercors' novel Le silence de la mer within the frame of the "cultural turn" in Translation Studies described by Lefevere (1992), Basnett (1998), Bassnett and Lefevere (1990 \& 1998), and Snell-Hornby (2006, pp. 47-68). This article aims to highlight and contextualize the role played by translation in cultural dynamics by emphasizing the institutional and ideological constraints imposed by Franco's censorship on the translation of a work imbued with political meaning. In this approach I will consider: 1) the agents that mediated the cultural transfer, which involves the reception and the translation of the novel; 2) the interpretation of symbolic key-words related to silence and language, as well as their adaptation in the translation; 3 ) the interpretation of the novel in a context of cultural and political repression.
\end{abstract}

Keywords: literary translation; dictatorship; Catalan; Spanish; cultural studies

"Quand on interdit l'accès à une langue, on n'interdit aucune chose, aucun geste, aucun acte. On interdit l'accès au dire, voilà tout, à un certain dire. Mais c'est là justement l'interdit fondamental, l'interdiction absolue, l'interdiction de la diction et du dire." Jacques Derrida. Le monolinguisme de l'autre ou la prothèse de l'origine. Paris: Galilée, 1996, p. 58.

\section{Introduction}

What is the function of translation within a dictatorship? How can activists use translations to resist fascism and its language? What is the social role of a minoritized language in a situation of political and cultural repression? The aim of this article is to provide some ideas which could help to answer these questions by analyzing the case of the circulation of the Catalan and Spanish translations of Vercors' novel Le silence de la mer. As is known, the book was first published clandestinely in 1942 and written by Jean Bruller under the pen name of Vercors.

In this study, I will examine the "context in which the translation takes place", the "history from which a text emerges and into which a text is transposed" and the role of power in both processes of writing and rewriting the text (Bassnett and Lefevere, 1990, pp. 11 \& 12). In the center of this analysis, I will consider that the political meaning of these two translations is based on the

Translation \& Interpreting Vol. 12 No. 2 (2020) 
image of the "spiritual fight" inherent in the violence of silence. In the Post World War II context, silence became a galvanizing value in relation to the community and it turned into a civil and positive gesture, almost as an act. As we will see, this idea can be related to Barthes' "a colourless writing, freed from all bondage to a pre-ordained state of language" (2012,p. 76), that is an innocent writing deprived from superfluous decoration, characterized by the "ideal absence of style" (2012, p. 77). In this sense, Vercors' work lacks pathos and aspires to a neutrality characterized by the absence of affection or subjectivity.

The article is divided into three parts: firstly, I will analyze the process of creation and circulation of Le silence de la mer (written in 1941) in its original space, the France of the Vichy regime; secondly, I will look at the cultural context of the translation of the book in Catalonia, in 1947, by considering the Spanish version of the work, published in Buenos Aires in 1944, and the role of the Catalan translator; and, finally, I will interpret some of the stylistic characteristics of the novel and its translation, by examining the literary influences which inspired it. This will enable the adoption of a model of analysis, common to the cultural perspective, that involves taking into consideration not only the text itself, but also the text that precedes it (the pretext) and its reception (Gentzler, 2017, p. 16); this approach highlights the belief systems of the original and receiving cultures. Following Lefevere, I am interested in the circulation and reception of the novel, in order to understand the role of both texts (the original and the translation) in both target systems. At the same time, I will look at the role of power in the cultural relationship which is the translation by highlighting the tensions resulting from a context of social inequality (Carbonell Cortés, 1999, p. 237) and cultural persecution.

This approach is framed within the cultural turn progressively adopted by translation studies since the 1980s. In that period, Snell-Hornby (1988) stated that translation is a "cross-cultural event" that obliges the translator not only to have a bilingual background but also bicultural training. The expression cultural turn, used by Bassnett and Lefevere (1990), would continue to form a central part of translation studies in the 1990s and it would open the discipline up to a discussion of areas not focused on linguistic or textual analyses. Eight years after the beginning of the debate, Bassnett (1998a and 1998b) highlighted that linguistics had also experienced its own cultural turn and estimated that the relationship between translation and cultural studies was one of the main factors that helped to revitalize both fields. Finally, she predicted that the link between translation and cultural studies was going to be expanded by including topics such as globalization, nationalisms, or power relations in a postcolonial context.

In the case studied in this paper, the context of cultural repression imposed by Franco's dictatorship between 1939 and 1952 entailed the prohibition of published works in Catalan, as well as translations (See Section 3). In the early years of Francoism, putting into circulation a clandestine translation like the one of Vercors' work, which was doubly banned (because of its political content and the use of a prohibited language), acquired a political meaning that was justified within the framework of a very specific power, and which worked, according to Foucault, in a way "that one should decipher in it a network of relations, constantly in tension, in activity, rather than a privilege that one might possess." (1977, p. 26). As we will see below, this power "is not exercised simply as an obligation or a prohibition on those who 'do not have it'; it is transmitted by them and through them [...] in their struggle against it" (1977, p. 27). In the analysis of the Catalan translation, I will take into account some discursive and textual elements related to context, which have to be interpreted from a cultural and political point of view. 
More specifically, I will observe the choices that the translator made to face up to a power that operated at all levels, whose state of constant tension was related to the strategies assumed by the Franco regime after the end of the Second World War in order to legitimize the dictatorship in a context where its two major allies (Germany and Italy) were defeated. The translators' agency and subjectivity will be analyzed by considering their role as individuals positioned within networks of power relationships in three literary systems (Spanish, Catalan and French), which act, according to Lefevere, "as a series of 'constraints', in the fullest sense of the word, on the reader, writer and rewriter" (1992, pp. 12-13).

\section{Le silence de la mer: Origin and interpretation}

Above all, Le silence de la mer is an iconic book and it is highly representative of the state of European culture during the Second World War. This is the result both of the theme that inspired it (silence) and the impact its circulation had at a time when its very publication was already a great achievement in itself. Much of the existing bibliography has therefore evaluated the book in relation to the cultural and editorial agents that made its appearance and circulation possible (Simonin, 2008; Cornellà-Detrell, 2007; Bartillat, 2008; Pla, 2008). As Vercors himself explained in his memoirs (1967), that act of publishing was not only a victory over the censorship imposed by the Vichy regime, using the means that were established in the clandestinity of the time, but also the creation of an alternative to the silence that had been adopted by many of the intellectuals of the French internal Resistance. In this sense, Simonin states that Le silence de la mer creates a new mode of writing in a context where literature was defeated and the anti-collaborationist press insisted on blaming literary works as being responsible for supporting the Vichy regime (2008, p. 43-76). In addition to proposing a viable model of committed literature, the novel demonstrated that there were clandestine publishers by means of which independent texts could be put into circulation (Simonin, 2008, p. $68 \& 71$ ).

The plot is simple: an officer from the German army occupies a room in a village house where the narrator lives with his niece. From February to July, over six months, the narrator, an old man, tells of how the officer (who is a composer) comes into the house with long monologues addressed to him and his niece and how he receives no reply. The officer uses his good, but rather stiff French to show his admiration for France and French culture and he expresses a desire for the twinning of the two nations to promote both cultures. As a sign of this future union, the narrator insinuates a possible sentimental relationship with the girl, while she unsuccessfully attempts to hide the profound impression the foreigner has made upon her. The story ends when the officer realizes the true nature of the Führer's plans (not at all idealist) and asks to be posted to the Russian front, leaving the house.

The political component of the books is due, basically, to the context in which it was published. The signing of the Franco-German Armistice led the Vichy government to take control over the occupied France, which was regulated in September 1940 under the Convention de la censure, signed by the Syndicat des Éditeurs and the authorities of the German occupation. This meant that a good part of the publications from that time came to be eyed with suspicion by both authorities and intellectuals. A climate of mutual distrust was created between intellectuals and made worse by the lack of access to information, meaning that any publication, regardless of its subject matter, 
could be seen as collabo or collaborationist propaganda. To remain silent was considered the most dignified option by most of the members of the resistance until the middle of 1941, when a few conflicting voices (among them Pierre de Lescure, Vercors and the publishers of the magazine La pensée libre, which first appeared in February 1941) considered that breaking the silence was necessary to avoid the tacit and normalized acceptance of the Vichy regime and the emergence of literature in French which was bound to it (Loiseau \& Payr, 1995). It would be the southern part of France, the free or nono (non occupée) zone, where most of the copies of the book were distributed, with the aim of "opening the eyes" of the sudards or Southerners (citizens living in the non-occupied France) and making sure that, during this period of relatively little conflict with the Germans in France, they were not seduced by the so-called vichyssoise (Vichy government's) propaganda.

The history of the text shows the contextual circumstances. Jean Bruller, the French printmaker and draughtsman, adopted the pseudonym Vercors (after the Vercors Massif, where the French resistance was active) to publish his first work - an allegorical novel in response to a commission by his publisher and inspired by several biographical events. This anonymous publication of Le silence de la mer, dated 20 February 1942, marked the establishment of Éditions de Minuit, a publishing house founded by Bruller himself along with the writer Pierre de Lescure with the aim of publishing clandestine works (Simonin, 2008, pp. 43-76). The book was printed manually and aimed at a restricted audience (only between 350 and 400 copies were made). It was acclaimed by French intellectuals because it fulfilled their horizon of expectations, since it offered a symbolic account about a situation of strangeness that had become familiar to most of the readers (Simonin, 2008, p. 67). In 1943, after being reprinted, the novel was fiercely attacked by the Communists, who entered the fray in the summer of 1941, because they claimed that the way Vercors portrayed the main character (the German officer) was condescending to the enemy.

Despite these criticisms, the book's repercussion on the international circuits was immediate: in the Fall of 1942, it was introduced in England, where it was published as a feuilleton in the Gaullist magazine Le Marsellaise. In just fifteen days, 10,000 copies of the book were sold in its first London French edition (Simonin, 2008, pp. 71-72). It was re-published in 1943 by Éditions du Cahiers du Silence, translated into English by Cyril Connolly the same year, and into Spanish by Lorenzo Varela, in an edition with a prologue by the writer Maurice Druon and an epilogue by Simone Garma which would appear in 1944 in Buenos Aires. In 1947 the French film director Jean-Pierre Melville made a film adaptation of it.

The book itself, written in 1941, synthesizes the civic resistance politics that were defended by the nuclei of the French internal Resistance (Simonin, 2008, p. 67). Their attitude was based on the position of a non-violent waiting game, in which individual and collective dignity were the key. It was encouraged by General Charles de Gaulle from London and opposed the sabotages and attacks on the German military carried out by the FTPF (FrancTireurs et Partisans Français). After January 1942, when the German presence in the occupied zone increased, these attacks grew, causing, as a counterresponse, an intensification of the repression (Dreyfus, 1996, pp. 143-171). But how is this civic resistance expressed in the book? Basically, through contention - a contention that, in a text occupying fewer than 100 pages, is related to the implicit violence of silence. The narrative simplicity and objectivity are essential for the symbolic efficiency of the work, where the moral stance of the characters stands out. Ultimately, the text defends the dignity of resisting the 
charme of an enemy who, once settled in the domestic space, normalizes an exceptional situation. The book included a manifesto where the author took a stand against the discourse of hatred and violence spread by a part of the clandestine press and presented Éditions du Minuit as a platform in favor of freedom of thought and in defense of "the spiritual purity of the men"i* (Vercors, 1967, pp. 211-212). This interpretation of silence as a free option reappears in Maurice Druon's preface to the London edition (1943). The French writer remembers the three years in which France lived under the sign of silence - a silence imposed by the physical presence of the enemy. For the author, this situation, while forcing thought into silence, did not result in a significant production of French literature in support of the occupation.

However, the ambiguity of the narration meant that a part of the core resistance protested against the message of the work because, they argued, it was too gentle in its treatment of Von Ebrennac, the main German character, and did not clearly advocate a position of active resistance. For Vercors, however, the true merit of the story was in the construction of an officer who respected and admired French culture, like Ernst Jünger in his time (a name mentioned in La bataille du silence). For this construction he was inspired by an episode reported by Andrés Gide in his Journal and by different Germans that he met personally. In these cases, contact with the enemy gave the author a sense of empathy.

Beyond the political message, most of the existing bibliography on the book underlines its literary qualities and, among them, the importance of ambiguity and suggestion in the construction of the plot (Konstantinović, 1969; Kidd, 1991; Cesbron \& Jacquin, 1999). The ambiguity in the author's reaction to the German enemy was also conditioned by biographical factors. Bruller was the son of a Francophile German protestant, who, like Von Ebrennac, was reluctant to accept the dangers of Nazism until the end of World War II. Finally, when he realized the extent of the atrocities, he died. Le silence de la mer is inspired by four other biographical episodes, which reflect the author's feeling of ambivalence: the encounter with a German skier in Montana in 1925; the officer who took one of Bruller's rooms during the occupation, whom the writer refused to greet; the German who came into his garden and talked to Vercors' wife about the beauty of the place; and the German babysitter of the writer's son, who acted cruelly towards an ant which bit her. In all these biographical experiences, German men are characterized by their kindness, while the women, like a former Von Ebrennac's girlfriend, are beautiful but wild. This perspective (which is partly reflected in the novel) clashes with the general haine anti-boche (anti-German hatred) which was widespread among French society during the Occupation (Wieviorka, 2013, pp. 107-108). In Le silence de la mer, the feeling of hatred is replaced by a passive rejection. This rejection is represented though the visual description of the female character's reactions. From the beginning of the plot, the anonymous niece of the narrator "initiates the resistance to [the occupier] and shows fortitude in persisting in her stance despite the uncle's scruples" (Kidd, 1991, p. 33). This strength helps to sustain the uncle's silence. She and her uncle refuse to break the silence through the "violence de langage" (violence of language) and both remain silent in the living room while they are sewing, knitting or reading in presence of the German officer.

It is important to remember that the time between the writing of the novel (1941) and the years of its dissemination (1942 and especially 1943) meant that

\footnotetext{
${ }^{\mathrm{i}}$ I have translated into English those French and Catalan texts which have not been translated before. I have marked these translations with an asterisk.
} 
part of the original message (the dignity of passive resistance) lost some of its meaning. Following the entry of the Parti Communiste Français (PCF) and its intellectuals into the war after the German invasion of Russia, the repression intensified (Wieviorka, 2013, pp. 441-466) and news came of concentration camps in French territory (Beigbeder, 1994, p. 172). All this obliged the author to change some passages (in the theatre adaptation of 1949) and add paratexts to the work (in the 1951 re-edition) (Beigbeder, 1994, pp. 175-176) to show a less passive stance by the author and his niece. The Spanish and Catalan versions, however, were based on the original 1941 text.

\section{The circulation of the book through the Spanish and Catalan versions}

In order to understand the political and cultural role of the translation of Vercors' work in Catalan literature, we need to examine the role that translations have had throughout the contemporary age. In general, translation has been seen as a complementary and consubstantial practice in relation to original literary production in Catalan. More specifically, it has had a key role in the development of a literary tradition in four great moments of history. First, the turn of the nineteenth and twentieth centuries (in the context of the Modernista movement which meant a review and modernization of all artistic disciplines). Second, the 1920s and 1930s (the period associated with diversification in cultural forms and practices as a result of the emergence of mass society). Third, the 1960s, when the Franco regime authorized the publication of translations. Finally, the period from the 1980s onward, when the restoration of democracy provided the necessary conditions for the establishment of the three literary systems in Spain, which were not Spanish: Basque, Galician and Catalan. These were recognized as co-official languages with Spanish: Basque in the Basque Country, Galician in Galicia, and Catalan in Catalonia, the Valencian Country and the Balearic Islands (Gallén, 2004a; Ortín, 2004). Historically, translation has had a fundamental role in Catalan literature and is considered an inseparable practice for literary learning and a path to "make up for certain and profound deficiencies in local literature"* through universalization (Fuster, 1972, pp. 137-138, 407).

Within this framework, the Franco dictatorship (1939-1975) signified a major break with the process of creating a literary tradition and also meant a massive step backwards for opportunities not only to publish in languages other than Spanish but also to have a voice in any form of modernity, freedom or dissidence with respect to the official authoritarianism. Between 1939 and 1952 public use of the Catalan language was prohibited, and it was banned in education and the publication of books, newspapers and magazines (Venuti, 2005, p. 197). This repression affected both the cultural platforms (publishers and bookshops) and the cultural agents (teachers and political and administrative figures). It was not until the 1960s that we could talk of a regularization of publications in Catalan, making a modern publishing market possible (Bacardí, 2012). Throughout the dictatorship there was a diglossic use of language by those Catalan speakers who, while being able to consume products in Catalan, especially from the 1960s, lived in a context where the more prestigious uses of language were attributed to Spanish (Rafanell, 2011).

The post-Civil War period from 1939 to 1945 (coinciding with the Second World War) was the harshest in terms of the control imposed by the censors (Bacardí, 2012; Gallofré, 2013). However, in Catalonia the first actions of cultural resistance were organized from 1942 onward (in private spaces) and 
these became more consolidated in 1945, the year in which the Franco regime, having distanced itself from the Axis powers that had just been defeated by the Allies, loosened its grip over some spaces, such as cultural and artistic magazines and literary circles (Samsó, 1994, p. 91). It was the period known as the breach. All of this, however, ended in the context of the clandestine publication of El silenci del mar (the Catalan version of Vercors' novel) in 1947, at the time when the political resistance of both people within Catalonia and those in exile was seen to have been weakened (Samsó, 1994, p. 97). In the same year, Bartolomé Barba, Civil Governor of Barcelona, was replaced by Eduardo Baeza Alegría and the "Law of Succession of the Head of State" was approved, making official the resolution by Franco that the nationalist victory of 1939 should continue stand, and implying an increase in police repression against clandestine political groups and a harshening of censorship (Samsó, 1994, p. 96).

In 1947, the Catalan translation by Jordi Sarsanedas took on a more specific meaning. Faced with a situation which pushed him, as both a writer and a citizen, to act against the silence resulting from the prohibition, he began to disseminate literature in which silence acquired a galvanizing value (Anglada, 2008). The translation was an individual act which went back to a political sense, linked to a specific community, and was interpreted as a civic and constructive action. At the same time, it was opposed to the positioning of certain writers such as Palau i Fabre, who refused to publish in a context of repression and only accepted the publications of exiled intellectuals (Gallén, 2004b). In the preliminary notes to the work, the translator underlines the symbolic and literary values of the text and highlights the significative importance of the motif of silence. For Sarsanedas the call for silence during the occupation did not come from fear but constituted a "personal" and "national dignity"* (1947b, p. 8). The translator also establishes an indirect parallelism between the fiction of the novel and the situation that he is experiencing during Francoism with reference to the existence of the "Silence of the people, of the men who wait and hope"*, which has the same force as an inner scream. In the face of rejection and abstention, the author considers that the work does not break the silence but "is born of the same silence and, giving it the specific form of the myth, clearly gives it its combative meaning"* (1947b, p. 9). In that, he coincides with George Steiner when, in "Silence and the Poet" (1966), he asserts that "The silence [...] is that which seemed the only adequate, the only decent, response to the violations of the human speech, to the political bestiality and mockery of man that had come over Western Europe" (Steiner, 1985, p. 15).

Sarsanedas' translation would not have been possible without two key dissemination outlets. One was the magazine Antologia dels fets, les idees $i$ els homes d'Occident (Anthology of western facts, ideas and people), which was created without authorization by Antoni Ribera (in 1947 the magazine launched the literary collection by the same name, the Antologia dels fets, les idees $i$ els homes d'Occident where the book appeared ${ }^{\mathrm{ii}}$ ). The other was the Institut Français, one of the most active cultural oases of the 1940s and 1950. Created by the French Ministry for Foreign Affairs in 1922, under the jurisdiction of the

ii In this collection, Sarsanedas published the poetry book A trenc de sorra and an excerpt from his translation of Sartre's Les jeux sont faits. It was a small-format magazine, with 57 pages and a print run of between 500 and 1,000 copies. 10 issues were published between May 1947 and May 1948. The magazine articles were published in Romance languages and English (Samsó, 1995, pp. 81-102). 
University of Toulouse, it acted as a center for primary and secondary school education (or lycée) from 1924, and from 1939 it had as its director Pierre Deffontaines, who would hold the position for 25 years (1939-1964) (Sarsanedas, 1994, p. 14; Samsó, 1995; Ardolino, 2004). From 1942 to 1945, the Institut cut its ties with the Vichy government and came under the umbrella of the University of Algiers, adopting the name of the National Association of Students of Foreign Languages (Sarsanedas, 1994, pp. 20-21).

The first news that we have of Vercors through the Institut Français is from 1944. That year Deffontaines, who was receiving French newspapers through his Post Office box in Perpignan, noted down in his personal diary that he had read the article "Souffrance de la France", describing life during the occupation $^{\text {iii }}$. Commissioned by the American magazine Life, Vercors had published it in the magazine Carrefour, on 17 December 1944, just after the Liberation. Two and a half years later, on 15 April 1947, Maurice Matet gave a talk on Le silence de la mer at the Literary Circle of the Institut Français. It seems that Sarsanedas, who spoke about it in a chronicle (Sarsanedas, 1947a), began his translation at that time, referring to it as a literary exercise that he undertook "for the love of it"*. The book was published by Antoni Ribera in October 1947 (Cornellà-Detrell, 2007; Pla, 2008) and, according to the translator, there were no problems in its distribution. Signing the translation with the initials J.S., it had a limited circulation (only 50 copies were published). It was received mainly by the members of the Circle - around 25 people who participated in the meetings and who had been involved one way or another in the magazines of the time.

The book, which was inaccessible to most readers, was disseminated through the magazine Antologia dels fets, les idees $i$ els homes d'Occident ${ }^{i v}$, where an extract of the translation appeared in November $1947^{\mathrm{v}}$. Four months later, the magazine published the epilogue with which Simone Garma, specialist in French theatre and teacher at the Alliance Française of Buenos Aires, has prefaced the Argentinean translation ${ }^{\mathrm{vi}}$. It was a detailed "commentary" of Le silence de la mer which offered an interpretation of the book from the point of view of the premise of the Neoclassical racinien decorum (based on Jean Racine's concept of decorum, which implies qualities such as containment, propriety, stiffness and dignity). This version also demonstrated the capacity for diffusion of the work through the contacts the magazine had established with cultural exiles in America, where it had a network of correspondents (Gallén, 2004b). It is important to underline here the fact that the translator, Lorenzo Varela, was a Galician who fought with the Republicans in the Spanish Civil War and was sent to the French concentration camp of Sant Cyprien in 1939. Later, he went into exile in Mexico in 1939 and finally moved to Buenos Aires,

iii Deffontaines' personal diary is unpublished. The French publisher of the book, François Lecheral, visited Barcelona in 1948, according the news published in $L a$ Nostra Revista, 33-34, September-October 1948, p. 341.

iv Sarsanedas also wrote a note about the novel in the Issue 1 supplement of Ariel (August 1948), where he highlights the contemporariness of the book, despite the limitations posed by the clandestinity of its circulation.

\footnotetext{
${ }^{v}$ Issue 7 (November 1947), pp. 25-29. The parts reproduced correspond to pages 20-25 and 37-41 of the book, where there are small stylistic changes, such as the substitution of the past perfect by the periphrastic perfect.

${ }^{\text {vi }}$ Issue 11 (March 1948), pp. 65-70. This text had been published previously in the newspaper La Nación on 2 July 1944.
} 
where he had lived as a child, in 1941. In Argentina he worked for several publishing houses: Poseidón, Nova, Losada and Ayacucho (Loedel Rois, 2013, p. 70). It was through Ayacucho that Varela published the Spanish translation of Vercors' book, a translation which came into being due to the impact of the English version, the re-publication of the original in London in 1943. This second edition of the French original was disseminated by the Gaullistes, or the Free French.

In her epilogue to the Spanish translation, Simone Garma stressed the courage that had been involved in organizing the publication of the book in occupied territory and explained the circulation of the London edition. For Garma, the structure of the novel was based on a struggle between two fields: monologue and silence (Vercors, 1944c). In the part concerning silence are two victims of the situation (the uncle and his niece, who are anonymous), whose purity lies, precisely, in their eloquent silence. In the part of the monologue we find the officer Werner von Ebrennac, an educated man who is sure that the occupation will end when French charity conquers German brutality. The naivety of the character (and his extreme idealism) leads him to return to the Russian front when he realizes the atrocities that the Nazi regime has carried out.

\section{The ethos of the translator}

It is also important to mention that Sarsanedas was just 23 years old when he embarked on his career as a writer, translator and activist with this book. In the Barcelona of 1947, the text could have been interpreted in two ways: as a parallel reading of the Francoist occupation in Catalonia and as a criticism of the acceptance of the dictatorship by the Allied forces. The recontextualization of the story and its re-reading from the sense of silence in the framework of clandestine cultural debates contribute to this interpretation. It is not surprising, then, that in 1946, in a text appearing in Ariel, Joan Triadú spoke of silence as a "vibrant way of saying things"* at a time when the word, in order to exist, should be screamed out loud (Cònsul, 1997, p. 51).

After Vercors' book, Sarsanedas did other translations from the French language which appeared in magazines (in Ariel and Occident) or in the emerging publishing houses at the beginning of the 1960s (Edicions 62, Estela and Nova Terra). Generally they were translations of contemporary literature which were used to introduce current topics such as life in the new state of Israel (L'État d'Israël, by André Chouraqui), concerns in the catholic or religiousthemed novel (Journal d'un curé de campagne, by Georges Bernanos), or the interest in existentialism as a form for expressing the human condition (Citadelle, d'Antoine Saint-Exupéry, translated jointly with Miquel Martí i Pol).

In general, Sarsanedas' task as a translator came, on the one hand, from the need for literary learning that would feed into his own writing and, on the other, the need to give a voice to authors who, at a particularly hostile time, were contributing not only to the modernization of the forced clandestinity of translation but also providing symbolic references that would enable him to stablish parallelisms (in both argument and form) with the western literature of the time. For Sarsanedas, translating was a move in favor of freedom. It was a profession that allowed the translator to augment the sense of what was real and possible and also one which was essential for the reader to gain access to the essential part of the original (Sarsanedas, 1988). Sarsanedas is, therefore, a 
predecessor of the "self-consciously political translator", followed twenty years later by the likes of M. Aurèlia Capmany, who saw translation as a key for the enrichment of Catalan culture and a means of cultural and civic resistance (Simon, 2012, p. 104).

In 1987, in the prologue to the republication (by La Magrana) of his translation, Sarsanedas highlighted the powerful and enriching density of the text. In his view, the book reflects "the stark reality of a decisive moment for the history of Europe"*, where the narration "gives weight and consistency to that which is not said"* (1987, p. 5). Silence, once again, is the center of eloquence in a narration which, bereft of its original political context, could also be seen as "a simple, also schematic, story of impossible love [...] presented in a form which is simple but brazenly artistic at its root; a painful anecdote of conflict between individual impulses and the course of history"* (1987, p. 5 \& 8). The book will be discussed by readers today from the angle of one of the motifs which inspired it: the story of frustrated young love. Its re-publication will revalidate its literary value and place in circulation a text which, in a different political context, takes on a different meaning.

\section{The symbolism of the blank page}

According to Venuti (2019), translation is an operation of interpretation. In the analysis of this interpretation process, the inherent references in the original text must be taken into account - in this case, inter-literary references. On adopting the symbol of silence, the work of Vercors creates a dialogue with part of the French, English and German literary traditions of the postwar period. Silence and the impossibility of writing was one of the central motifs of reflection generated by the Second World War (Cornellà-Detrell, 2007). In his analysis of the relationship between language and silence, written in 1966, Steiner talks of a "sense of the work of art as entrapped, diminished when it is given articulate form [...] grounded in historical circumstance, in a late stage of linguistic and formal civilization in which the expressive achievements of the past seemed to weight exhaustively on the possibilities of the present" $(1985$, p. 68). As Steiner sees it, the political inhumanity of the twentieth century and certain aspects of technological society of the masses have affected language, especially at times when the stability and expressive authority of central European civilization seemed to be abandoned (1985, pp. 73-74). In times of war, the option of silence is seen as an alternative to human atrocity; an atrocity that provides the ambiguous figure of Von Ebrennac in the novel with a political function: that of the occupier. Thanks to the silence, language ceases to be a neutral sanctuary that neutralizes the barbarity. The title of the book itself, where the silence is attributed to the sea, it sends a warning message to the reader, flagging up the deceptive calm of the ocean (Vercors, 1967, pp. 186-187).

As we have seen, in the context of World War II, Vercors' aesthetic options were also determined by his ethical purposes. He aimed to deal with a controversial topic in a new way, not only for artistic reasons, but to avoid dangerous simplifications of the truth (Konstantinović, 1969, p. 65). More precisely, Bruller wanted to condemn the silence of Germans facing the degradation of humanity resulting from Hitler's regime (Bartillat, 2008, p. 77) ${ }^{\mathrm{vii}}$. Although the anticipated audience was French, we can consider that,

\footnotetext{
vii Engel (1999, p. 281) offers a new reading of the novel which contradicts Vercors' explicit purposes. By analyzing images where silence is associated with heaviness and Translation \& Interpreting Vol. 12 No. 2 (2020) 
among the readers of the book, there could also have been some German intellectuals, like Jünger, who defended the virtues of humanism. The characterization of Von Ebrennac, a musician in his civil life, is rooted in humanism when he insists on convincing his listeners (the two other characters and the readership) of the importance of the values of European culture in a context of moral and cultural debacle (Kidd, 1991, p. 26). In general terms, this approach to the 'other', or the German, fits in with the idea that the work of Vercors is based on "humanism touched by existentialism"*, in the words of Jordi Sarsanedas (1987, p. 6).

Beyond its humanist message, the narrative efficiency of the book lies basically in its structural and narrative simplicity on the one hand, and, in the use of an ambiguous and allegorical symbolism on the other. The structural scheme that sustains Le silence de la mer is justified not only by the political message, but also in the narrative pretext that it holds: the story of frustrated love, inspired, in turn, by an autobiographical experience. In his memoirs, the author himself justifies Rilke's character by arguing he was inspired by the need to write of the young Malte Laurids Brigge: "something has to happen. The first person to come, the one who has had disturbing thoughts, must begin to do something for the one who has been neglected [...] since there is no other. This Brigge, this foreigner, this insignificant young man will have to sit down and, on the fifth floor, will have to write day and night. Yes, he will have to write, that's how it will end"* (Vercors, 1967, p. 245).

The story is told from an internal focus (the uncle, the main character, is the narrator) and centers on everyday moments when the three characters (the uncle narrator, the niece and the German official) coincide in the living room, usually in the mornings and evenings. These moments form the structural base of the story, essentially reiterative and reported in the past. The writer centers the plot in the interior of the house without providing any information about the exterior events. This choice benefits the imagination of the reader, who is forced to fill in the blanks (Edge, 1999). This narrative difficulty is reinforced by two of the more distinctive narrative techniques in Vercors' fiction: the juxtaposition of situations which create tension (Pickering, 1999, p. 68) and the use of description as a devise to insinuate feelings (Démiroglou, 1999). As far as the sources are concerned, in La bataille du silence Vercors indicates that he is inspired by two models: the fable "Silence" by Edgar Allan Poe, which tells how the devil condemns man to live in a world without sound, and the work of Joseph Conrad which inspires the use of an objective narrator. The author confesses that this objectivity obliges him to describe the characters from the outside: through "their gestures, the hands which betray them, the words always charged with ambiguity, the silences which unveil them without arousing their suspicion"* (1967, p. 185). In addition to the influences of Poe and Conrad, there is also the impact of Shakespeare's Hamlet (Konstantinović, 1969). During the Occupation, Bruller translated and illustrated this play, but, in his version, he made changes in order to accuse Hamlet of being responsible, for a lot of deaths, due to his hesitancy to take action (Calin, 1999, p. 378). According to Konstantinović, "Von Ebrennac is a composite of Hamlet and the ghost (father and son). He is also the projection of his creator, Vercors alias Jean Bruller, failing to measure up to events in 1940" (1969, p. 44).

The entire force of the story comes from this use of an external description applied to certain elements (gestures, hands, faces) which, on becoming

darkness, he argues that in the book the silence is enslaved by words, because words are under the exclusive control of the German enemy. 
substitutes for words, acquire central importance and which, being constantly repeated throughout the text, condition the syntax. As Konstantinović explains, most of these narrative techniques came from the experience Bruller acquired as an illustrator. I will introduce four of these techniques, which will be analyzed in more detail to explain specific excerpts of the novel and its translation into Catalan. Firstly, Konstantinović (1969, p. 116-117) describes how the narrative voice focuses on the depiction of frequent static scenes, in which silence is associated with immobility. Secondly, he observes the author's interest for words or elements related to visual language, like the vocabulary of colors, the creation of a backlight effect and the description of silhouettes (Konstantinović, 1969, p. $121 \&$ 132). Auditive references are, according to Konstantinović, another of the significant elements of the narrator's prose, in tune with the importance of the word silence, whose value changes depending on the context: it can express a wide range of feelings, like malaise, melancholy or suffocation. In total, this word is used 30 times in a text of 10,800 words (Konstantinović, 1969, p. 150). Finally, he refers the inclusion of dramatic elements, like the description of gestures or the observation of external signs (Konstantinović, 1969, p. 164).

In this last section, I will look at three examples where silence acquires different characteristics and connotations. The first one comes from the beginning of the novel; in his first night in the house, the officer himself apologizes for the occupation and asks to be shown to his room. The fragment starts with a description ("le silence se prolongeait"), and is followed by a double adjectivization of the silence ("épais" et "immobile"), which results from the narrator and niece's actions (they "alourdissaient ce silence" et "le rendaient de plomb"). This scene, purely descriptive, alternates with the nonactions taken by the occupier, who "restait immobile" with un smile "grave" and without "nulle trace d'ironie":

Le silence se prolongeait. Il devenait de plus en plus épais, comme le brouillard du matin. Épais et immobile. L'immobilité de ma nièce, la mienne aussi sans doute, alourdissaient ce silence, le rendaient de plomb. L'officier lui-même, désorienté, restait immobile, jusqu'à ce qu'enfin je visse naître un sourire sur ses lèvres. Son sourire était grave et sans nulle trace d'ironie. Il ébaucha un geste de la main, dont la signification m'échappa. Ses yeux se posèrent sur ma nièce, toujours raide et droite, et je pus regarder moi-même à loisir le profil puissant, le nez proéminent et mince. (Vercors, 1944a, pp. 17-18 ${ }^{\text {viii) }}$

Sarsanedas' translation keeps the syntactical repetitions and alternation of tenses (between passé simple and imparfait) of the original, as well of the description of the mysterious final gesture and the man's stony-faced profile:

El silenci es prolongava. Esdevenia més i més espès, com la boira del matí. Espès i immòbil. La immobilitat de la meva neboda, la meva també, afeixugaven el silenci, el feien de plom. L'oficial mateix, desorientat,

viii Cyril Connolly's English version: "The silence was unbroken, it grew closer and closer like the morning mist; it was thick and motionless. The immobility of my niece, and for that matter my own, made it even heavier, turned it to lead. The officer himself, taken aback, stood without moving till at last I saw the beginning of a smile on his lips. His smile was serious and without a trace of irony. With his hand he made a vague gesture whose meaning I did not grasp, and fixed his eyes on my niece, still standing there stiffly, so that I had leisure to examine his strong profile, his thin and prominent nose" (Vercors, 1944b, p. 4). 
romania immòbil, fins que, en fi, vaig veure un somriure als seus llavis. El seu somriure era greu i sense cap rastre d'ironia. Esbossà amb la mà un gest el sentit del qual se m'escapà. Els seus es posaren en la meva neboda, encara tibada i dreta, i vaig poder contemplar jo mateix a pleret el perfil vigorós, el nas prominent i prim (Vercors, 1947, p. 17)

The second description takes place some days later, when the recurrent visits of Von Ebrennac have become normal. In this example, Vercors depicts the nervousness of the situation through the fine description of the "vivacité mécanique" of the niece's knitting:

Il demeura sans bouger assez longtemps, sans bouger et sans parler. Ma nièce tricotait avec une vivacité mécanique. Elle ne jeta pas les yeux sur lui, pas une fois. Moi je fumais, à demi allongé dans mon grand fauteuil douillet. Je pensais que la pesanteur de notre silence ne pourrait pas être secouée. Que l'homme allait nous saluer et partir.

Mais le bourdonnement sourd et chantant s'éleva de nouveau, on ne peut dire qu'il rompit le silence, ce fut plutôt comme s'il en était né. (Vercors, $1944 \mathrm{a}$, p. $27^{\mathrm{ix}}$ )

In his translation, Sarsanedas maintains the oral suggestions of the original, especially when he translates the metaphorical bourdonnement (buzzing) with brunziment, managing to keep the idea of the animalization of the German occupier's voice. According to the narrator, Von Ebrennac's words originate the necessary (and heavy) silence:

Romangué sense moure's força temps, sense moure's i sense parlar. La meva neboda feia mitja amb vivacitat mecànica. No girà el seu esguard cap a ell, ni una vegada. Jo fumava, mig allargat en la meva gran butaca flonja. Pensava que no es podria saccejar la feixuguesa del nostre silenci. Que l'home saludaria i se n'aniria.

Però el brunziment sort $\mathrm{i}$ cantant s'alçà novament. No es pot dir que trenqués el silenci; fou més aviat com si n'hagués nascut. (Vercors, 1947, p. 23)

After having travelled to Paris, Von Ebrennac realizes that his dream of a union between Germany and France will not be possible. His deep disappointment leads him to decide to go and fight at the Russian front. This final excerpt describes his last visit to the family; one more time, the silence is related to heaviness and oppression, but its characterization adds a new visual element - darkness:

\section{-Nevermore!}

Le silence tomba une fois de plus. Une fois de plus mais, cette fois, combien plus obscur et tendu! Certes, sous les silences d'antan, —comme, sous la calme surface des eaux, la mêlée des bêtes dans la mer,- je me sentais bien grouiller la vie sous-marine des sentiments cachés, des désirs et des pensées qui se nient et qui luttent. Mais sous celui-ci, ah! rien qu'une affreuse oppression...

ix "He remained for a long time without moving or saying anything. My niece was knitting with machinelike energy, nor did she once look up at him. I was smoking, half stretched out in my big soft armchair. I imagined that nothing could disturb the weight of our silence, that the man would bid us good-night and go. But he muffled and musical buzzing began again; one couldn't say that it broke the silence, for it seemed to be born out of it." (Vercors, 1944b, p. 10). 
La voix brisa enfin se silence. Elle était douce et malheureuse. (Vercors, 1944a, p. $81^{x}$ )

Like Vercors, Sarsanedas decides to make the silence fall in a dramatic scene which seems to announce the end. While the novel hints at the future suicide of the officer, it does not give any hope for the future of the narrator and his niece:

-Never more.

El silenci caigué de bell nou encara una vegada. Encara una vegada; però, aquesta vegada, més obscur i tibant. Evidentment, sota els silencis d'antany — com, sota la superfície tranquil·la de les aigües, la brega de les bèsties en el mar- sentia bellugar-se la vida submarina dels sentiments amagats, dels desigs i dels sentiments que es neguen i lluiten. Però sota aquest, ai!, sols una espaordidora opressió...

La veu per fi rompé el silenci. Era dolça i desventurada. (Vercors, 1947, p. 57)

In Sarsanedas' translation we see the desire to reproduce "the same set of senses and suggestions, the same wealth of reading possibilities, yet still reproducing the same form, rhythmic and sonorous, as the original"* (1988, p. 46). As mentioned before, this rhythmic and sonorous dimension of the work is achieved through the reiteration of a symbology associated with silence based on the repetition of words related to visual vocabulary fields: "gesture", "eyes", "voice" (communicative elements which act as substitutes for the words) and in maintaining the same syntactic order as the original. Concerning this last point, the syntactic and lexical simplicity of the original, typical of Vercors' bare style, makes its translation easier. On a narratological level, the style is expressed in the predominance of parataxis and the use of short, simple phrases linked by conjunctions. All of these characteristics make the book appealing for a writer like Sarsanedas, who makes "precision and economy"* (Munné Jordà, 1997, p. 202) the distinctive traits of his literature.

\section{Conclusion}

The translations of Vercors' work demonstrate the existence of "interpretative communities" which determine the circulation of both the translations themselves and possible future rewritings (Lefevere, 1992, p. 8). Written with a great economy of means, the circulation of Le silence de la mer is due to its political significance, the use of stylistically neutral prose which is easy to translate, and the way it situates the symbol of silence - a word that would acquire great galvanizing power during the immediate post-war period- at the center of the conflict. The reception of the work in Catalonia, which was conditioned by repression of the Franco dictatorship, intensifies the political sense of the original (also present in the previously published Spanish version) and shows, once again, that "the borders transgressed in translation tend to be more multiple and permeable than traditionally conceived" (Gentzler, 2017, p.

\footnotetext{
$x$ "Nevermore! Once more the silence fell. Once more, but this time how much more tense and thick! Underneath our silences of the past I had indeed felt the submarine life of hidden emotions, conflicting and contradictory desires and thoughts swarming away like the warring creatures of the sea under the calm surface of the water. But beneath this silence, alas! there was nothing but a terrible sense of oppression. At last his voice broke the silence. It was gentle and distressed." (Vercors, 1944b, p. 41).
} 
5). The translation brings the silence to light. Or, as Sarsanedas says in a poem published in A frec de sorra: "from that light of yours I have silence on my lips"*.

\section{Acknowledgement}

This paper is part of the research carried out with the aid of a postdoctoral position funded by the Department of Translation Studies and Language Sciences, Universitat Pompeu Fabra. It has been carried out within the framework of the TRILCAT consolidated research group of the Universitat Pompeu Fabra (http://trilcat.upf.edu).

\section{References}

Anglada, M.-À. (2008). Temps de silenci. In M. À. Anglada, Incitació a la lectura. Articles de crítica literària (pp. 27-31). Edited by Eusebi Ayensa and Francesc Foguet. Publicacions de l'Abadia de Montserrat.

Ardolino, F. (2004). La solitud de la paraula. Estudi sobre l'obra narrativa de Jordi Sarsanedas. Publicacions de l'Abadia de Montserrat.

Bacardí, M. (2012). La traducció catalana durant el franquisme. Punctum.

Barthes, R. (2012). Writing and silence. In R. Barthes, Writing degree zero (A. Lavers \& C. Smith, Transl.) (pp. 74-78). Foreword by Adam Thirlwell. Hill and Wang. (Original work published 1956)

Bartillat, C. (2008). Vercors: L'homme du siècle à travers son æuvre, 1902-1991. Presses du village.

Bassnet, S. (1998a). Still trapped in the labyrinth: Further reflections on translation and theater. In S. Bassnet, Constructing cultures. Essays on literary translation (pp. 90-108). Multilingual Matters.

Bassnet, S. (1998b). The translation turn in cultural studies? In S. Bassnet, Constructing cultures. Essays on literary translation (pp. 123-140). Multilingual Matters.

Bassnet, S. \& Lefevere, A. (1990). Proust's grandmother and the thousand and one nights. The 'cultural turn' in translation studies. In S. Bassnet, \& A. Lefevere (Eds.), Translation, history and culture (pp. 1-13). Pinter Publishers.

Bassnet, S. \& Lefevere, A. (1998). Where are we in translation studies? In S. Bassnet, Constructing cultures. Essays on literary translation (pp. 1-11). Multilingual Matters.

Beigbeder, Y. (1994). Postface. In Vercors, Le silence de la mer (pp. 163-180). Albin Michel.

Calin, F. (1999). Au-delà du circonstanciel: Une relecture du Le silence de la mer. In G. Cesbron \& G. Jacquin (ed.), Vercors (Jean Bruller) et son oeuvre (pp. 367378). L'Harmattan.

Carbonell Cortés, O. (1999). Traducción y cultura: De la ideología al texto. Ediciones Colegio de España.

Cesbron, G. \& Jacquin, G. (ed.) (1999). Vercors (Jean Bruller) et son oeuvre. L'Harmattan.

Cònsul, I. (1997). El primer Sarsanedas. In Sobre Jordi Sarsanedas (pp. 41-53). Publicacions de l'Abadia de Montserrat.

Cornellà-Detrell, J. (2007). The endless night of Xavier Benguerel: A critical approach to El Testament. Bulletin of Hispanic Studies, 84(2), 223-238.

Démiroglou, E. (1999). Un courant sous-jacent de signification ou le paisible péril du silence dans Le silence de la mer. In G. Cesbron \& G. Jacquin (ed.), Vercors (Jean Bruller) et son oeuvre (pp. 343-353). L'Harmattan.

Dreyfus, F.-G. (1996). Histoire de la Résistance 1940-1945. Prefaced by the abbot from Naurois. Éditions de Fallois.

Edge, F. (1999). Le silence de la mer, le rôle clé de l'imagination. In G. Cesbron \& G. Jacquin (ed.), Vercors (Jean Bruller) et son oeuvre (pp. 139-146). L'Harmattan. 
Engel, V. (1999). Il ne reste que le silence: Parole, silence et écriture dans le recueil de Vercors Le silence de la mer. In G. Cesbron \& G. Jacquin (ed.), Vercors (Jean Bruller) et son oeuvre (pp. 279-294). L'Harmattan.

Foucault, M. (1977). Discipline and punish. The birth of the prison (A. Sheridan, Transl.). Pantheon Books.

Fuster, J. (1972). Literatura catalana contemporània. Curial.

Gallén, E. (2004a). La traducción entre el siglo XIX y el Modernisme. In F. Lafarga, \& L. Pegenaute (Eds.), Historia de la traducción en España (pp. 661-673). Ambos Mundos.

Gallén, E. (2004b). Sota la bota de Franco. Apunt sobre la cultura clandestina. In J. Font Agulló (Dir.), Franquisme i repressió: La repressió franquista als Països Catalans (pp. 47-78). Universitat de València.

Gallofré, M. J. (2013). Autarquia i localisme: Les traduccions a la immediata postguerra. Quaderns. Revista de traducció, 20, 69-75.

Gentzler, E. (2017). Translation and rewriting in the age of post-translation studies. Routledge.

Kidd, W. (1991). Vercors: "Le silence de la mer", et autres récits: A critical introduction to the wartime writing. University of Glasgow French and German Publications.

Konstantinović, R. (1969). Vercors, écrivain et dessinateur.C. Klincksieck.

Lefevere, A. (1992). Translation, rewriting and the manipulation of literary fame. Routledge.

Loedel Rois, G. (2013). Los traductores del exilio republicano español en Argentina. [Doctoral dissertation, Universitat Pompeu Fabra. Retrieved from https://www.tdx.cat/handle/10803/108338

Loisaux, G. \& Payr, B. (1995). La Littérature de la défaite et de la collaboration: D'après Phönix oder Asche? (Phénix ou cendres?). Fayard.

Munné Jordà, A. (1997). Estalvi i riquesa: La llengua literària de Jordi Sarsanedas. In Sobre Jordi Sarsanedas (pp. 187-203). Publicacions de l'Abadia de Montserrat.

Ortín, M. (2004). Las traducciones, del Noucentisme a la actualidad. In F. Francisco, \& L. Pegenaute (Eds.), Historia de la traducción en España (pp. 674-694). Ambos Mundos.

Pickering, R. (1999). Mesurer le silence: L’écriture du moindre dans les récits de Vercors. In G. Cesbron \& G. Jacquin (ed.), Vercors (Jean Bruller) et son æeuvre (pp. 61-72). L'Harmattan.

Pla, X. (2008). Jordi Sarsanedas, més enllà del silenci. Serra d'Or, 578(February), 1719.

Porter i Moix, M. (1994). Memòria dels cercles de l'Institut Francès. Hacer Editorial.

Rafanell, A. (2011). La destrucció del català durant el franquisme. In A. Rafanell, Noticies d'abans d'ahir. Llengua i cultura catalanes al segle XX (pp. 349-523). Acontravent.

Samsó, J. (1994). La cultura catalana: Entre la clandestinitat i la represa pública. V. 1. Prefaced by Josep Benet. Publicacions de l'Abadia de Montserrat.

Samsó, J. (1995). La cultura catalana: Entre la clandestinitat i la represa pública. V. 2. Publicacions de l'Abadia de Montserrat.

Santerbás, S. R. (2015). Introducción. In Vercors, El silencio del mar y otros relatos clandestinos (pp. 7-42). Cátedra.

Sarsanedas, J. (1947a). Els cercles de l'Institut Francès. Ariel, year 2, 9(April), 30.

S.[arsanedas], J. (1947b). Nota preliminar. In Vercors, El silenci del mar (J. S., Trans.) (pp. 7-10). Antologia del Fets, les Idees i els Homes d'Occident.

Sarsanedas, J. (1987). Pròleg a la present edició. In Vercors, El silenci del mar (J. Sarsanedas, Transl.) (pp. 5-8). Illustrated by Agustí Roca. Edicions de La Magrana, L'esparver.

Sarsanedas, J. (1988). Humilitat i rigor, per damunt de tot. Serra d'Or, 348 (November), 45-46.

Sarsanedas, J. (1994). Introducció. Monsieur Deffontaines, grand merci. In M. Porter i Moix (coord.), Memòria dels cercles de l'Institut Francès (pp. 11-24). Editorial Hacer. 
Simon, S. (2012). Cities in translation. Intersections of language and memory. Routledge.

Simonin, A. (2008). Les Éditions de Minuit, 1942-1955: Le devoir d'insoumission. IMEC Éditions. (Original work published 1994)

Snell-Hornby, M. (1988). Translation as a cross-cultural event. In M. Snell Hornby, Translation studies. An integrated approach (pp. 39-64). John Benjamins.

Snell-Hornby, M. (2006). The turns of translation studies. New paradigms on shifting viewpoints? John Benjamins.

Steiner, G. (1985). Silence and the poet. In G. Steiner, Language and silence (pp. 5574). Faber and Faber.

Tymoczko, M. \& Gentzler, E. (2002). Translation and power. University of Massachusetts Press.

Venuti, L. (2005). Local contingencies. Translation and national identities. In S. Berman, \& M. Wood (Eds.), Nation, language and the ethics of translation (pp. 177-201). Princeton University Press.

Venuti, L. (2019). Contra instrumentalism. A translation polemic. University of Nebraska Press.

Vercors (1944a). Le silence de la mer. Éditions de Minuit. (Original work published 1942)

Vercors (1944b). The silence of the sea (C. Connolly, Transl.). Prefaced by M. D. [Maurice Druon], published in England under the title Put out the light. The Macmillan Company.

Vercors (1944c). El silencio de Francia (L. Varela, Transl.). Prefaced by M.D. [Maurice Druon], with an epilogue of Simone Garma. Ayacuco.

Vercors (1947). El silenci del mar (J. S., Transl.). Antologia del Fets, les Idees i els Homes d'Occident.

Vercors (1967). La bataille du silence. Souvenirs de minuit. Presses de la Cité.

Vercors (1987). El silenci del mar (J. Sarsanedas, Transl.). Illustrated by Agustí Roca. Edicions de La Magrana, L'esparver.

Wieviorka, O. (2013). Histoire de la Résistance 1940-1945. Perrin. 